\title{
Grote variatie in gebruik van prestatie-indicatoren bij gemeenten
}

\author{
Tjerk Budding, Erwin Ormel, Martijn Schoute
}

\author{
\begin{tabular}{l|l|l|l} 
Received 7 October 2019 & Accepted 2 November $2019 \quad$ Published 11 December 2019
\end{tabular}
}

\section{Samenvatting}

Nederlandse gemeenten zijn al geruime tijd bezig met de ontwikkeling en het gebruik van prestatie-indicatoren. Met ingang van de begroting 2017 zijn gemeenten verplicht om een lijst uniforme indicatoren in hun begroting en jaarrekening op te nemen. Dit artikel laat aan de hand van onderzoek op basis van meer dan 100 verantwoordingsstukken zien dat 40,2\% van de gemeenten momenteel volstaat met het alleen presenteren van de verplicht voorgeschreven indicatoren. Tevens vinden we dat het gebruik van outcome-indicatoren beperkt is. Ten slotte treffen we een zekere mismatch aan tussen de financiële omvang van de taakgebieden van gemeenten en het aantal indicatoren dat per taakgebied wordt gepresenteerd.

\section{Relevantie voor de praktijk}

Gemeenten zijn al geruime tijd bezig met het identificeren van prestatie-indicatoren die aansluiten bij de gebruikersbehoeften. Onze waarneming dat momenteel een aanzienlijk deel van de gemeenten volstaat met het alleen presenteren van verplichte indicatoren doet het vermoeden rijzen dat deze gemeenten zich de moeite willen besparen om daar zelf nog in te investeren. Dit roept de vraag op hoe nuttig het gebruik van indicatoren dan daadwerkelijk wordt ervaren. Verder ambieert dit artikel een spiegel voor te houden over de mate waarin indicatoren aansluiten bij het belang van de verschillende taken van gemeenten, alsmede of er genoeg in termen van maatschappelijke toegevoegde waarde wordt gerapporteerd.

\section{Trefwoorden}

prestatie-indicatoren, verslaggeving gemeenten

\section{Inleiding}

Nederlandse gemeenten zijn al geruime tijd bezig met het definiëren, meten en rapporteren van prestatie-indicatoren in hun verantwoordingsdocumenten. In de loop der jaren zijn er diverse initiatieven ontplooid om gemeenten ertoe te bewegen om hier een goede invulling aan te geven. Terwijl het gemeenten tot voor kort vrij stond om volledig naar eigen inzicht en behoefte prestatie-indicatoren op te nemen in de begroting en jaarrekening, is het sinds het begrotingsjaar 2017 verplicht om een set uniforme financiële en beleidsindicatoren te publiceren. In dit artikel gaan wij na wat dit in de praktijk betekent. Wellicht kiezen gemeenten er nu voor om te volstaan met het alleen gebruiken van de voorgeschreven indicatoren. Verder gaan we na welke soorten indicatoren worden gebruikt. In de literatuur wordt wel gesteld dat er in het huidige publieke management meer aandacht zou moeten zijn voor de maatschappelijke effecten (de outcomes) van het beleid. Wij gaan na welke mix aan indicatoren er daadwerkelijk wordt gebruikt. Ten slotte analyseren wij in hoeverre er sprake is van een match tussen het financiële belang van de verschillende taakgebieden van gemeenten en de aandacht die daar in de vorm van indicatoren aan wordt besteed. Hierbij trekken we een parallel met het informativeness principle dat veelal wordt gebruikt voor onderzoek naar prestatie-indicatoren in het bedrijfsleven. Dit beginsel stelt dat het van belang is om aandacht te geven aan aspecten die werkelijk zicht geven op de handelingen die actoren verrichten om de doelen van de organisatie te bereiken. 
In dit artikel gaan we eerst in op relevante inzichten die uit de theorie over het werken met prestatie-indicatoren naar voren komen (paragraaf 2). Daarna zullen wij in paragraaf 3 een korte uiteenzetting geven van de institutionele achtergrond van het werken met prestatie-indicatoren bij gemeenten. Vervolgens geven wij in paragraaf 4 aan hoe wij ons onderzoek hebben uitgevoerd, gevolgd door een presentatie van de resultaten in paragraaf 5. Daarna komen we in paragraaf 6 tot onze conclusies en bespreken we de uitkomsten kort in het licht van relevante literatuur.

\section{Theorie prestatie-indicatoren}

In de accountingliteratuur is er in de afgelopen decennia aanzienlijke aandacht besteed aan de ontwikkeling en het gebruik van prestatiemaatstaven. Terwijl deze tot aan de jaren zestig vooral betrekking hadden op financiële aspecten, kwam er vanaf die tijd meer aandacht voor niet-financiële elementen (Kaplan and Johnson 1987). Laatstgenoemde was er niet alleen op gericht om een breder palet aan factoren in beschouwing te nemen die zicht geven op het functioneren van de organisatie, het vestigde ook meer de aandacht op zogeheten leading factoren, dat wil zeggen die factoren die toekomstige doelbereiking beïnvloeden, zoals de mate waarin de organisatie zich blijft innoveren.

Veel publicaties over prestatie-indicatoren hanteren als theoretische basis de agency theory. Deze theorie gaat er vanuit dat er relaties kunnen worden onderscheiden tussen een principaal die als opdrachtgever optreedt, en een agent die de opdrachtnemer is. Tussen beide actoren bestaat informatie-asymmetrie, dat wil zeggen dat beide partijen niet over dezelfde (hoeveelheid) informatie beschikken. Vanwege mogelijk opportunistisch gedrag van de agent, wil de principaal zich ervan vergewissen dat de agent taken op een adequate manier uitvoert, en om de kans daarop te vergroten wordt het van belang geacht om goede afspraken te maken over de taakuitvoering en om te monitoren wat de agent doet. De kosten die hiermee gemoeid gaan worden respectievelijk bonding en monitoring costs genoemd (Jensen and Meckling 1976).

In de literatuur die gebruik maakt van de agency theory speelt nog een ander principe een belangrijke rol: het informativeness principle. Dit principe stelt dat prestatiemaatstaven niet zozeer de aandeelhouderswaarde (uitgedrukt in zaken als winst, dividend en ontwikkeling van de aandelenkoers) zouden moeten uitdrukken, maar betrekking moeten hebben op maatstaven die adequaat de bijdrage van medewerkers aan de waardecreatie reflecteren (Indejejikian 1999). Het hanteren van deze maatstaven draagt ertoe bij zicht te krijgen op die handelingen van medewerkers die leiden tot deze waardecreatie, dit worden ook wel de value drivers genoemd. Als we de grondgedachte van het informativeness principle hanteren voor de publieke sector, dan behelst dit principe dat er met name aandacht is voor die zaken die waarde (value) toevoegen voor de maatschappij, en dat zijn dan met name de maatschappelijke resultaten (outcomes). Or- ganisaties in de publieke sector zijn over het algemeen inkomensbestedende en geen inkomensverwervende organisaties, kortom het doel is niet zozeer om inkomsten te verwerven, maar juist om inkomsten zo goed mogelijk te besteden (zie bijv. Budding and Bac 2004; Gerritsen 2007). Daarom verwachten we dat de mate waarin er wordt gerapporteerd over beleidsterreinen in belangrijke mate correspondeert met het financiële belang (de inkomensbesteding) van die beleidsterreinen. Dit geldt al helemaal bij gemeenten, waarbij het de gemeenteraad is die de baten en lasten op basis van haar politieke preferenties accordeert, en die ook de primaire gebruiker is van de begroting en de jaarrekening.

Terwijl de literatuur rond het gebruik van prestatiemaatstaven in het bedrijfsleven zich derhalve met name richt op het meten van en sturen op die aspecten die van belang zijn voor de waardecreatie, heeft de theorie die zich richt op de publieke sector met name betrekking op de condities waaronder er kan worden gewerkt met prestatiemaatstaven. Onder invloed van het zogeheten New Public Management gingen overheden in vele landen ertoe over om meer te gaan werken met prestatiemanagement. Vanuit de wetenschap klonken hierover de nodige waarschuwingen dat lang niet alle situaties daar geschikt voor waren. Zo is de politieke omgeving, met zijn wisselende politieke preferenties, mogelijk een belemmering om te sturen op indicatoren, omdat degenen die beoordeeld worden te maken hebben met wisselende doelstellingen waar zij zich op moeten richten (De Bruijn 2006). Tevens is er de nodige aandacht voor mogelijke belemmeringen voor de invoering van prestatiemanagement. Hierbij wordt met name gewezen op problemen rond het definiëren en meten van prestatie-indicatoren. Dat deze factoren in de praktijk inderdaad als problematisch worden gezien, blijkt ook uit onderzoek van Budding and Griep (2010). Zij vroegen ambtenaren bij gemeenten die bezig zijn met het thema prestatiemanagement welke belemmeringen zij ervaren voor de invoering van prestatiemanagement. Hierbij kwamen definitie- en meetproblemen met respectievelijk $55,7 \%$ en $29,6 \%$ als de belangrijkste factoren naar boven (zie tabel 1).

Tabel 1. Belemmeringen invoering prestatiemanagement.

\begin{tabular}{l|c}
\multicolumn{1}{c}{ Belemmering } & $\begin{array}{c}\text { Door respondenten als } \\
\text { grootste of als één na grootste } \\
\text { belemmering genoemd }\end{array}$ \\
\hline Definitieproblemen & $55,7 \%$ \\
\hline Meetproblemen & $29,6 \%$ \\
\hline Onvoldoende medewerking & $29,4 \%$ \\
middenmanagement & \\
\hline Beperkingen informatiesysteem & $19,8 \%$ \\
\hline Te tijdrovend & $19,8 \%$ \\
\hline Te lage prioriteit ambtelijke top & $19,7 \%$ \\
\hline Te lage prioriteit politiek & $16,4 \%$ \\
\hline Onvoldoende training & $5,5 \%$ \\
medewerkers & \\
\hline Onvoldoende middelen & $3,2 \%$ \\
vernieuwing & \\
\hline Bron:Budding andGrien & \\
\hline
\end{tabular}

Bron: Budding and Griep (2010) 
Een andere ontwikkeling die de nodige gevolgen heeft gehad voor het denken over prestatie-indicatoren binnen de publieke sector is de verschuiving van de zogeheten managementparadigma's. Vanaf het eind van de negentiende eeuw tot het einde van de jaren zeventig van de twintigste eeuw prevaleerde de zogeheten Traditional Public Administration (TPA). Ten opzichte van de periode daarvoor betekende TPA een sterke professionalisering van het openbaar bestuur en werden de rollen van de politiek en het ambtelijk apparaat meer gescheiden en geëxpliciteerd. De aansturing was vooral gericht op het borgen van regels en processen, waaronder het zich houden aan relevante wet- en regelgeving en het binnen de budgetten blijven (Wiesel and Modell 2014). De verantwoording was dan ook met name daarop gericht. Vanwege twijfels over de efficiëntie en effectiviteit van de overheid kwam eind jaren zeventig het paradigma van New Public Management (NPM) op. De nadruk op het zich houden aan wet- en regelgeving maakte plaats voor aandacht voor efficiëntie en financiële resultaten (Wiesel and Modell 2014). Er werden in deze periode diverse praktijken en instrumenten overgenomen uit het bedrijfsleven, zoals het gebruikmaken van prestatie-indicatoren en kostprijzen. Al vrij snel na de opkomst van NPM - reeds in de jaren tachtig - kwam er echter de nodige kritiek op gang op dit paradigma, die zich vooral richtte op de vraag of de vanuit het bedrijfsleven overgenomen technieken en instrumenten wel pasten binnen de publieke sector. Bovendien werd het steeds duidelijker dat de overheid (slechts) een coproducent was bij de oplossing van maatschappelijke vraagstukken die veelal complex van aard zijn. Kortom, samenwerkende netwerken dienden het primaire uitvoeringsmechanisme te zijn. Hierbij was het belangrijkste doel te werken aan effectiviteit en klant- c.q. burgertevredenheid (Wiesel and Modell 2014). De focus qua sturing zou dan op inter-organisatorische processen en outcomes moeten liggen. Voor deze nieuwe gedachten over het public management zijn diverse noemers in omloop, waaronder New Public Governance en Public Value Management. Vanwege het ontbreken van een consistente naam wordt er tegenwoordig simpelweg gesproken over het post-NPM paradigma. Daarnaast komt in toenemende mate het besef naar boven dat in plaats van het compleet plaatsmaken van het ene paradigma voor het andere, er in de praktijk veel meer sprake lijkt te zijn van een combinatie van elementen die uit verschillende paradigma's afkomstig zijn (Hyndman and Liguori 2016). In het empirische deel van ons artikel gaan we na in hoeverre de vanuit de managementparadigma's gesuggereerde ontwikkeling van het sturen op budgetten (dus een nadruk op de geconsumeerde middelen, de inputs) en op de processen via een nadruk op de outputs (vanwege de focus op efficiëntie) naar meer aandacht voor outcomes (maatschappelijke resultaten) in de praktijk zichtbaar is. In tabel 2 hebben we een definitie van de verschillende soorten indicatoren opgenomen.

Zoals zal blijken uit de volgende paragraaf, zijn er de nodige initiatieven ontplooid om gemeenten ertoe aan te zetten om te gaan werken met prestatie-indicatoren. In de praktijk bleek nogal eens dat de uitwerking van managementvernieuwingen achterbleef bij de verwachtingen die daarvan waren. Ter Bogt and Van Helden (2000) wezen in het kader van accountinghervormingen bij Nederlandse gemeenten al eerder op een kloof tussen verwachtingen en uitkomsten, die ze onder meer toeschreven aan een gebrek aan betrokkenheid van het topmanagement (zie ook tabel 1).

Eén van de benaderingen die wel wordt gehanteerd voor het verklaren van het uitblijven van resultaten van vernieuwingen is die van DiMaggio and Powell (1983). Zij geven aan dat er sprake kan zijn van het verschijnsel van isomorphisme, dat wil zeggen het hanteren van gelijkvormige instrumenten. Dat er daarvan sprake is, wil echter nog niet zeggen dat deze instrumenten dan ook weloverwogen en adequaat worden gebruikt. Door DiMaggio and Powell (1983) worden er drie soorten c.q. oorzaken van isomorphisme onderscheiden:

Tabel 2. Definitie soorten prestatie-indicatoren.

In dit artikel gaan we uit van de indeling en beschrijving van soorten prestatie-indicatoren zoals geformuleerd door Ter Bogt and Van Helden (1994) en Jansen (2004):

Input-indicatoren:

- Bij input-indicatoren gaat het om de meting (in hoeveelheid geld of fysieke inputs) van duurzame en niet-duurzame productiemiddelen die in het productieproces worden gebruikt.

Proces (throughput)-indicatoren:

Procesindicatoren meten de activiteiten en/of de kenmerken daarvan (bijv. ziekteverzuim), die door de betrokken organisatie worden uitgevoerd gedurende het productieproces.

Output-indicatoren:

- Output-indicatoren geven de uitkomsten van het productieproces weer in het aantal te behalen of gerealiseerde producten of diensten. De outputs onderscheiden zich van de throughputs door de directe consumptie door burgers. Een kenmerk van deze indicatoren ten opzichte van de outcome-indicatoren is dat de gemeente hier direct invloed op heeft, zoals het aantal paspoorten.

Outcome-indicatoren:

- Outcome-indicatoren geven het maatschappelijk effect weer van de geleverde output. Dit effect is het eindresultaat van het productieproces. Het gaat bij deze indicatoren om de uiteindelijke resultaten (en de kwaliteit) van de outputs. De invloed van de gemeente op de maatschappelijke effecten is indirect, namelijk via outputs.

Kengetallen:

- Niet door de gemeente beïnvloedbare gegevens. 
Gedwongen (coercive) isomorphisme, die een gevolg is van zowel formele als informele druk vanuit andere organisaties waarvan men afhankelijk is, zoals van de Rijksoverheid.

Mimetisch (mimetic) isomorphisme, die veelal het gevolg is van onzekerheid, waardoor organisaties elkaar gaan imiteren. Het idee is dat organisaties in onzekere omstandigheden er vaak naar neigen zich te spiegelen aan vergelijkbare organisaties die als succesvol worden ervaren.

Normatief (normative) isomorphisme, die voornamelijk voortkomt uit professionalisering. Professionals hebben vaak een gerichte opleiding gevolgd, een eigen kennisbasis en eigen professionele netwerken, die van invloed zijn op de vorming van hun normen.

\section{Institutionele achtergrond}

Vanuit de ambitie meer een koppeling te leggen tussen financiële middelen en maatschappelijke resultaten, begonnen gemeenten begin jaren zeventig van de vorige eeuw met een project onder de titel "Beleidsanalyse Gemeenten" dat hierop was gericht. Dit project was echter geen lang leven beschoren. In de tweede helft van de jaren tachtig startte het ministerie van Binnenlandse Zaken en Koninkrijksrelaties een nieuw initiatief, het Beleids en Beheers Instrumentarium (BBI)-project. Het project was erop gericht om planning en control-beslissingen in gemeenten te faciliteren door het verbeteren van de informatievoorziening, waaronder het gebruik van prestatie-indicatoren (Budding et al. 2019). Het BBI-project liep van 1987 tot 1995 en één van de onderdelen was om de traditionele indeling van verantwoordingsdocumenten, die gebaseerd was op beleidsterreinen (zoals sociale zekerheid, onderwijs, infrastructuur), los te laten en te vervangen door een productgerichte indeling, meer gericht op specifieke diensten (zoals huisvesting basisonderwijs, onderhoud kanalen), de gerelateerde kosten en opbrengsten, alsmede prestatie-indicatoren. Er is het nodige onderzoek gedaan naar het succes van BBI en op basis van een meta-studie daarvan liet Aardema (2002) zien dat in veel gevallen gemeenten prestatie-indicatoren niet zozeer gebruiken om beleidsresultaten te laten zien, maar deze meer illustratief opnemen. Een impuls voor de koppeling tussen beleid en middelen vormde de vernieuwing van de verslaggevingsvoorschriften in 2004. In dat jaar werd het Besluit begroting en verantwoording provincies en gemeenten van kracht dat gemeenten verplichtte voortaan een programmabegroting te publiceren. De programmabegroting kan daarbij worden gezien als een beleidsdocument waarin de politieke prioriteiten, toekomstige activiteiten, de gerelateerde financiële middelen en de te bereiken maatschappelijke doelen geëxpliciteerd moesten worden. Verder was het advies vanuit het ministerie van Binnenlandse Zaken en Koninkrijksrelaties om voor ieder programma - dat overigens naar eigen inzicht gedefinieerd mocht worden - drie vragen te beantwoorden:

1. Wat willen we bereiken?

2. Wat gaan we daarvoor doen?

3. Wat mag het kosten?

De eerste vraag zou daarbij beantwoord moeten worden door het definiëren van doelen en effecten. Als dat gebeurd is, kunnen programma's en activiteiten worden gespecificeerd die deze doelen en effecten beogen te realiseren (vraag 2). Ten slotte dienen de budgetten te worden bepaald die daar dan voor nodig zijn (vraag 3).

Uit een formele evaluatie door adviesbureau BMC in opdracht van het ministerie van Binnenlandse Zaken en Koninkrijksrelaties (Schilder et al. 2010) kwam onder meer naar voren dat programmabegrotingen vooral 'verhalen vertellende'-informatie over beleidsissues presenteerden, in plaats van dat er een directe link werd gelegd tussen beleid en financiële middelen. Uit een enquête die deel uitmaakte van het onderzoek bleek ook dat slechts $28,6 \%$ van de ondervraagden een positief antwoord gaf op de vraag: 'De indicatoren in de programmabegroting spelen een belangrijke rol in de discussie over dit document in de gemeenteraad' (Schilder et al. 2010, p. 37). Eén van de redenen waarom het in de praktijk gecompliceerd lijkt om een relatie te leggen tussen beleidsambities en resultaten aan de ene kant en financiële middelen aan de andere kant, is dat het lastig wordt gevonden om de juiste prestatie-indicatoren te selecteren en gebruiken.

Een volgende belangrijke wijziging vond plaats in 2015. Deze wijziging vond met name plaats omdat gemeenten problemen ervoeren als ze kosten en prestaties wilden vergelijken (zie Budding and Ormel 2018). De oplossing hiervoor was tweevoudig. Ten eerste schreven de nieuwe regels voor dat gemeenten hun overheadkosten niet meer mochten doorrekenen aan de beleidsonderdelen (programma's en producten) in hun begroting en jaarrekening. Alle overheadkosten moesten voortaan zichtbaar worden gemaakt onder het programma 'bedrijfsvoering'. Ten tweede schreven de nieuwe regels voor dat gemeenten uniforme indicatoren moesten publiceren in hun financiële verantwoordingsdocumenten, te weten vijf financiële indicatoren en 39 beleidsindicatoren. De financiële indicatoren hadden vooral ten doel om een wat breder en diepgaander inzicht te geven in de huidige en toekomstige financiële weerbaarheid van de gemeente. Een voorbeeld is de indicator 'belastingcapaciteit' die informatie verschaft over de mate waarin lokale belastingen kunnen worden verhoogd. De beleidsindicatoren hebben betrekking op diverse gebieden, variërend van informatie over de mate waarin gemeenten extern personeel inhuren tot informatie over het percentage inwoners dat niet aan sport doet. In dit artikel richten wij ons alleen op de beleidsindicatoren. Voor een analyse van de financiële indicatoren verwijzen wij naar Budding and Ormel (2018). 


\section{Het onderzoek}

Om meer inzicht te krijgen in de vraag hoe gemeenten op dit moment omgaan met prestatie-indicatoren, hebben wij voor een selectie van 107 gemeenten dit gebruik in kaart gebracht (zie tabel 4, panel A). We hebben geen gebruikgemaakt van een random steekproef omdat van deze gemeenten al de nodige andere informatie beschikbaar was waar we mogelijk ook een koppeling mee wilden leggen. Meer specifiek waren de geanalyseerde gemeenten op een eerder moment respondent in een onderzoek naar uitbesteding door gemeenten, waarbij we de gemeenten die inmiddels zijn heringedeeld of waarvan geen begroting beschikbaar was, buiten de steekproef hebben gelaten. Hoewel de steekproeftrekking derhalve niet willekeurig heeft plaatsgevonden, blijkt de onderzoeksgroep wel goed verdeeld te zijn over de verschillende bij gemeenten te onderscheiden groottecategorieën. Ook hebben wij geen aanwijzingen dat deze gemeenten op andere kenmerken niet representatief zouden zijn voor de volledige populatie.

Tabel 3. Aantal opgenomen verplichte indicatoren.

\begin{tabular}{l|c}
\multicolumn{1}{c}{ Aantal verplichte indicatoren } & Aantal gemeenten (percentage) \\
\hline 22 & $1(0,9 \%)$ \\
\hline 27 & $1(0,9 \%)$ \\
\hline 28 & $1(0,9 \%)$ \\
\hline 29 & $1(0,9 \%)$ \\
\hline 30 & $1(0,9 \%)$ \\
\hline 31 & $3(2,8 \%)$ \\
\hline 32 & $5(4,7 \%)$ \\
\hline 34 & $10(9,3 \%)$ \\
\hline 35 & $15(14,0 \%)$ \\
\hline 36 & $4(3,7 \%)$ \\
\hline 37 & $8(7,5 \%)$ \\
\hline 39 & $29(27,1 \%)$ \\
\hline Totaal & $13(12,1 \%)$ \\
\hline
\end{tabular}

Ons onderzoek richtte zich primair op de begroting 2019 van Nederlandse gemeenten. Artikel 4 van het BBV schrijft echter voor dat de begroting en het jaarverslag een identieke indeling dienen te hebben.
Daarom veronderstellen wij dat het beeld dat naar voren komt bij de begroting ook representatief is voor de jaarverslagen. Vanwege het moment van het beschikbaar komen van de jaarrekeningen (veelal pas kort voor de zomervakantie) hebben wij ervoor gekozen om ons op de begrotingen in plaats van op de jaarrekeningen te richten. Onderstaande overzichten en analyses zijn dan ook daarop gebaseerd.

\section{Uitkomsten van het onderzoek}

Zoals hiervoor aangegeven, zijn gemeenten sinds het begrotingsjaar 2017 verplicht om een set uniforme financiële en beleidsindicatoren op te nemen in hun begroting en jaarrekening. De door ons geanalyseerde begroting 2019 is daarmee de derde begroting waarvoor deze verplichting geldt. Wij zijn als eerste aspect in onze analyse nagegaan hoe gemeenten met deze verplichting omgaan. Houden ze zich wel aan de wet en nemen ze wel alle verplichte indicatoren op? En heeft de eis van de verplichte indicatoren er wellicht toe geleid dat gemeenten zijn gestopt met het zelf definiëren van indicatoren?

Terwijl er in de begroting 2017 nog 39 verplichte beleidsindicatoren opgenomen moesten worden, is dit aantal voor de begroting 2019 tot 37 gedaald. Uit onze analyses (zie tabel 3) blijkt dat slechts $27,1 \%$ van de gemeenten precies het aantal van 37 verplichte indicatoren gebruikt. Een groep van 26,2\% hanteert ook nog indicatoren die op een eerder moment nog verplicht waren en dat nu niet meer zijn. Mogelijkerwijs vinden deze gemeenten deze indicatoren nog steeds relevant. Een andere verklaring kan zijn dat zij zich niet van het vervallen van het verplichte karakter van deze indicatoren bewust zijn. Ten slotte is er nog een groep van $46,7 \%$ van de gemeenten die zich feitelijk niet aan de wet houdt en een aantal verplichte indicatoren 'vergeet' te gebruiken. Overigens wil het niet opnemen van deze informatie niet zeggen dat deze informatie volledig ontbreekt. Op de website www. waarstaatjegemeente.nl is deze informatie namelijk wel opgenomen. Dit is ook mogelijk omdat de hiervoor benodigde data niet door gemeenten zelf, maar door andere instanties is aangeleverd.

Tabel 4. Kenmerken steekproef per groottegroep.

\begin{tabular}{|c|c|c|c|c|c|c|c|}
\hline & \multirow{2}{*}{\multicolumn{3}{|c|}{$\begin{array}{c}\text { Panel A } \\
\text { Hele steekproef }\end{array}$}} & \multicolumn{4}{|c|}{ Panel B } \\
\hline & & & & Hele steekproef & $\begin{array}{l}\text { Gemeenten in stee } \\
\text { niet-verplichte in }\end{array}$ & proef & \\
\hline & $\begin{array}{l}\text { Aantal gemeenten } \\
\text { in steekproef }\end{array}$ & $\begin{array}{l}\text { Aantal gemeenten } \\
\text { in Nederland }\end{array}$ & $\begin{array}{l}\text { Percentage } \\
\text { gemeenten in } \\
\text { steekproef }\end{array}$ & $\begin{array}{l}\text { Percentage gemeenten met } \\
\text { niet-verplichte indicatoren } \\
\text { (aantal gemeenten) }\end{array}$ & $\begin{array}{l}\text { Gemiddeld aantal } \\
\text { niet-verplichte } \\
\text { indicatoren }\end{array}$ & Min. & Max. \\
\hline$<20.000$ inwoners & 29 & 81 & $35,8 \%$ & $51,7 \%(15)$ & 26,6 & 1 & 142 \\
\hline $20-50.000$ inwoners & 51 & 189 & $27,0 \%$ & $56,9 \%(29)$ & 28,2 & 1 & 133 \\
\hline $50-100.000$ inwoners & 18 & 54 & $33,3 \%$ & $72,2 \%(13)$ & 53,9 & 14 & 138 \\
\hline $100.000+$ inwoners & 9 & 31 & $29,0 \%$ & $77,8 \%(7)$ & 112,4 & 71 & 186 \\
\hline Totaal & 107 & 355 & $30,1 \%$ & $59,8 \%(64)$ & 42,3 & 1 & 186 \\
\hline
\end{tabular}


In het vervolg van dit artikel richten wij ons met name op de niet-verplichte indicatoren. Als eerste stap in de analyse van het gebruik daarvan zijn wij nagegaan in hoeverre gemeenten naast de verplichte indicatoren ook niet-verplichte indicatoren gebruiken. Overigens rekenen wij vanwege de leesbaarheid onder de verplichte indicatoren ook die indicatoren die in een eerder stadium verplicht waren, en dat nu niet meer zijn. Uit tabel 4, panel B, blijkt dat slechts 59,8\% van de gemeenten ervoor kiest om naast de verplichte indicatoren ook niet-verplichte indicatoren te gebruiken. Met andere woorden, 40,2\% volstaat met het alleen publiceren van de verplichte indicatoren. Er blijken aanzienlijke verschillen tussen de onderscheiden groottegroepen, kleine gemeenten gaan er minder vaak toe over $(51,7 \%$ bij de groep gemeenten met minder dan 20.000 inwoners) dan grote gemeenten $(77,8 \%$ bij de groep gemeenten met meer dan 100.000 inwoners). Als we vervolgens verder kijken naar hoeveel niet-verplichte indicatoren er gemiddeld worden gebruikt, dan ligt dit aantal op 42,3 indicatoren. Er is echter sprake van een aanzienlijke mate van spreiding. Zo is er een gemeente die slechts één niet-verplichte indicator opneemt in de begroting 2019, maar ook één waarbij dit aantal op 186 ligt. Ook hier zien we grote verschillen tussen de groottegroepen. Grote gemeenten hanteren gemiddeld genomen aanzienlijk meer niet-verplichte indicatoren dan kleine gemeenten (zie figuur 1 voor een voorbeeld van niet-verplichte indicatoren door een grote gemeente). In het verlengde hiervan nemen we waar dat het minimum aantal niet-verplichte indicatoren bij de $100.000+$ gemeenten op 71 ligt, terwijl dit aantal bij de groep 50-100.000 gemeenten 14 bedraagt. Wel zien we hierbij dat er binnen elke groottegroep sprake is van een aanzienlijke mate van spreiding. Zo heeft één kleine gemeente met minder dan 20.000 inwoners in onze steekproef maar liefst 142 indicatoren (zie ook figuur 2 voor een voorbeeld van een kleine gemeente met veel indicatoren).

Een good practice van een grote gemeente treffen we aan in de Begroting 2019 van de gemeente Eindhoven. De gemeente Eindhoven hanteert naast de verplichte indicatoren ook 120 niet-verplichte indicatoren. De gemeente Eindhoven hanteert de taakveldindeling voor de onderverdeling in programma's. Per taakveld worden hierin de doelen en de prestaties beschreven. Zowel de doelstellingen als de prestaties zijn vervolgens weer kwantitatief vertaald in indicatoren, zoals figuur 1 laat zien.

Een good practice van een kleinere gemeente die indicatoren in de gemeentebegroting hanteert, is de gemeente Urk. Urk neemt de indicatoren programmagewijs op als een soort van bijlage achterin de begroting. Urk hanteert 133 niet-verplichte indicatoren.

Zoals behandeld in paragraaf 1 van dit artikel, wordt er in de literatuur wel gesteld dat we nu in een periode zitten waarin er binnen het publieke management meer aandacht is voor de maatschappelijke waarde, oftewel de outcomes. We zouden dan ook verwachten dat gemeenten een aanzienlijk deel van de indicatoren daarop richten (zie tabel 2 voor een definitie van de soorten indicatoren). Om hier meer zicht op te krijgen kijken wij zowel naar de verplichte als de niet-verplichte indicatoren. Bij de ver-

Figuur 1. Good practice Indicatoren. Gemeente Eindhoven Begroting 2019, p. 53. https://eindhoven.begroting-2019.nl/

Effect-indicatoren voor het taakveld samenkracht en burgerparticipatie:

Effectindicatoren
$\%$ inwoners met beperkte eigen kracht
$\%$ inwoners dat niet meedoet
$\%$ inwoners dat behoort tot de categorie
meest geïsoleerd

\begin{tabular}{rrr|} 
Realisatie & Begroting & Begroting \\
\hline 2017 & $\mathbf{2 0 1 8}$ & $\mathbf{2 0 1 9}$ \\
$8 \%$ & $\leq 7 \%$ & $\leq 7 \%$ \\
$5 \%$ & $\leq 4 \%$ & $\leq 4 \%$ \\
$6 \%$ & $\leq 5 \%$ & $\leq 5 \%$
\end{tabular}

Prestatie-indicatoren voor het taakveld samenkracht en burgerparticipatie:

\begin{tabular}{|r|r|r|} 
Begroting & Begroting & Begroting \\
\hline 2020 & $\mathbf{2 0 2 1}$ & $\mathbf{2 0 2 2}$ \\
$\leq 7 \%$ & $\leq 7 \%$ & $\leq 7 \%$ \\
$\leq 4 \%$ & $\leq 4 \%$ & $\leq 4 \%$ \\
$\leq 5 \%$ & $\leq 5 \%$ & $\leq 5 \%$
\end{tabular}

\begin{tabular}{|c|c|c|c|c|c|c|}
\hline \multirow[t]{2}{*}{ Prestatie-indicatoren } & Realisatie & Begroting & Begroting & Begroting & Begroting & Begroting \\
\hline & 2017 & 2018 & 2019 & 2020 & 2021 & 2022 \\
\hline $\begin{array}{l}\text { \% nieuwe meldingen dat door } 1 \mathrm{e} \text { lijn } \\
\text { (Stichting WIJeindhoven) direct wordt } \\
\text { afgehandeld door verwijzing naar de sociale } \\
\text { basis }\end{array}$ & $21 \%$ & $32 \%$ & $33 \%$ & $34 \%$ & $35 \%$ & $36 \%$ \\
\hline $\begin{array}{l}\text { Oordeel cliëntenraad SD (i.o.) over } \\
\text { betrokkenheid inwoners bij beleidsvorming }\end{array}$ & nvt & 6,5 & 6,5 & 7 & 7 & 7 \\
\hline $\begin{array}{l}\text { \% inwoners doorverwezen naar sociale } \\
\text { basis door Stichting WIJeindhoven } \\
\text { (afschaling) }\end{array}$ & & & $\mathrm{nnb}$ & $\mathrm{nnb}$ & $\mathrm{nnb}$ & $\mathrm{nnb}$ \\
\hline
\end{tabular}


Figuur 2. Good practice kleine gemeente met veel indicatoren. Gemeente Urk Programmabegroting 2019, p. 135. https://www.urk. nl/mgd/files/Programmabegroting\%202019-2022.pdf

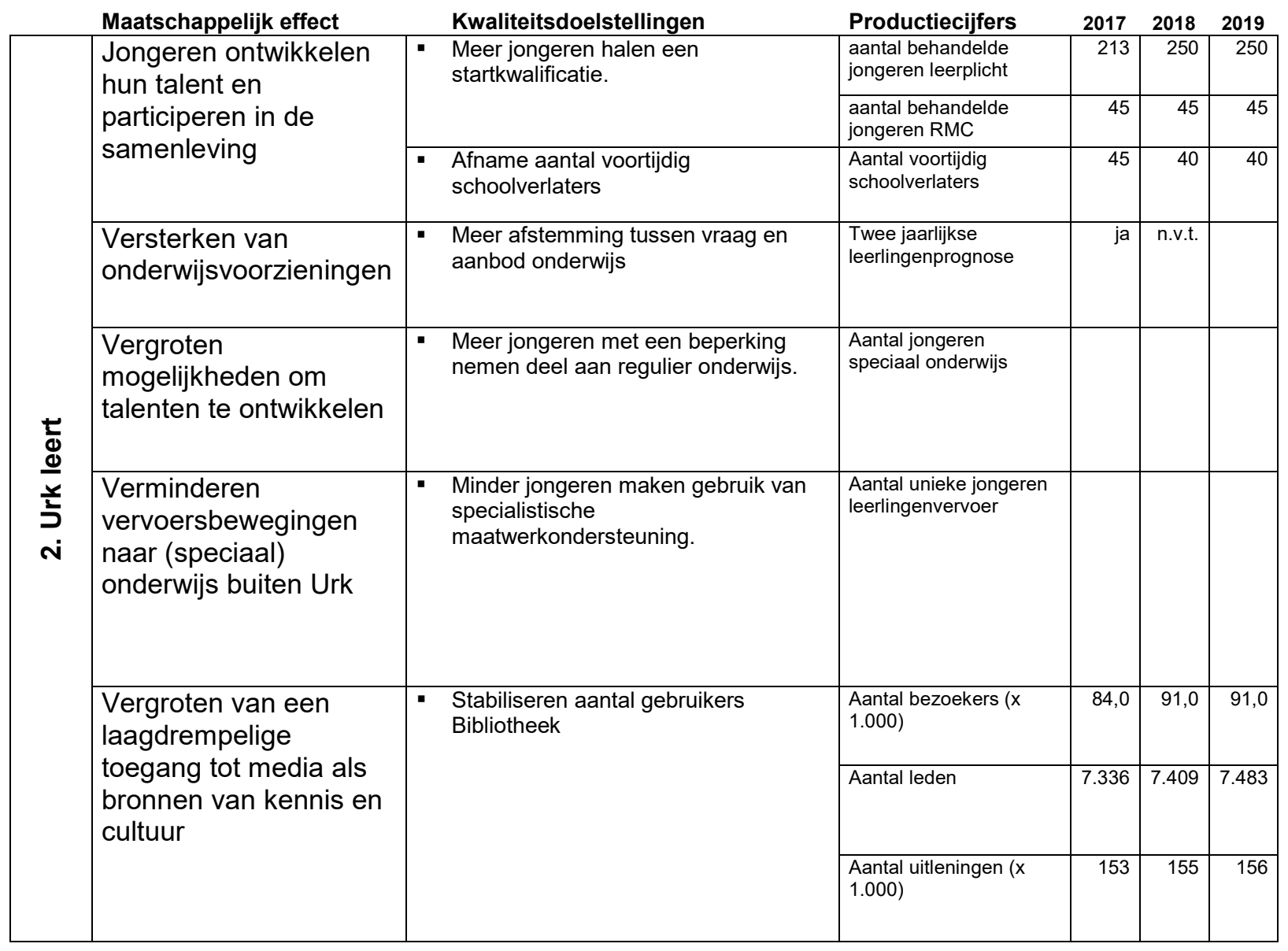

plichte indicatoren komt daarbij het beeld naar voren dat deze zich vooral op de output richten (zie tabel 5, panel A), 30 van de 37 verplichte indicatoren hebben daarop betrekking. Verder hebben vijf indicatoren betrekking op de input en zijn er twee te beschouwen als kengetal.

Als we vervolgens kijken naar de aard van de niet-verplichte indicatoren (zie tabel 5, panel B), dan vinden we dat iets meer dan de helft van de niet-verplichte indicatoren een output-indicator is. Verder is $33,4 \%$ van de niet-verplichte indicatoren een outcome-indicator. Ten slotte zien we dat $8,6 \%$ van de indicatoren een kengetal is. Het aantal input- en procesindicatoren is met respectievelijk $0,3 \%$ en 3,9\% van de indicatoren zeer beperkt. Tussen de verschillende groottegroepen zijn er enige verschillen, maar deze lijken weinig systematisch.

In panel $\mathrm{C}$ van tabel 5 hebben we het gemiddelde beeld van de indicatoren weergegeven, dat naar voren komt als we alleen die gemeenten beschouwen die ook niet-verplichte indicatoren hanteren. Het blijkt dat dan slechts $13,7 \%$ van de gebruikte indicatoren als outcome-indicator kan worden aangemerkt. Dat aantal varieert wel sterk tussen de groottegroepen: bij de gemeenten met minder dan 20.000 inwoners is $9,1 \%$ van de indicatoren een outcome-indicator, terwijl dit percentage bij de 100.000+ gemeenten op 23,8\% ligt. De meest gebruikte soort indi- catoren zijn output-indicatoren. $71,8 \%$ van de gebruikte indicatoren heeft daarop betrekking en dit beeld zien we grofweg bij alle groottegroepen, alhoewel het percentage bij met name de $100.000+$ gemeenten iets lager ligt (vanwege het hogere percentage outcome-indicatoren). Input-indicatoren zijn in volgorde van belangrijkheid de volgende soort die onderscheiden kan worden, 7,5\% van de gebruikte indicatoren betreft een dergelijke indicator. Terwijl dit soort indicatoren nog relatief vaak door kleine gemeenten wordt opgenomen in de begroting, is dit relatief beperkt bij de grote gemeenten. De hekkensluiter vormen de procesindicatoren. Blijkbaar vinden gemeenten het van minder belang om expliciet te rapporteren over procesgerichte aspecten, zoals doorlooptijden. Een bijzondere categorie wordt ten slotte gevormd door kengetallen, die feitelijk niets over de door de gemeenten behaalde prestaties zeggen, maar meer betrekking hebben op de achtergrondkenmerken die van belang zijn voor het uitvoeren van activiteiten, zoals demografische aspecten. Deze kengetallen vormen gemiddeld 5,5\% van de indicatoren.

Als volgende stap in onze analyse zijn we nagegaan in hoeverre het financiële belang van de verschillende taakvelden waarop gemeenten actief zijn zich uit in aandacht daarvoor in de vorm van indicatoren. We zouden op grond van het informativeness principle, alsmede op 
Tabel 5. Aard van de indicatoren.

\begin{tabular}{|c|c|c|c|c|c|c|c|}
\hline & Steekproef & Groep & Input & Proces & Output & Outcome & Kengetal \\
\hline $\begin{array}{l}\text { Panel A: Verplichte } \\
\text { indicatoren }\end{array}$ & Alle gemeenten** & Alle gemeenten & $5,0(13,5 \%)$ & $0,0(0,0 \%)$ & $30,0(81,1 \%)$ & $0,0(0,0 \%)$ & $2,0(5,4 \%)$ \\
\hline \multirow{5}{*}{$\begin{array}{l}\text { Panel B: Niet- } \\
\text { verplichte indicatoren }\end{array}$} & \multirow{5}{*}{$\begin{array}{c}\text { Gemeenten in } \\
\text { steekproef met niet- } \\
\text { verplichte indicatoren }\end{array}$} & $<20.000$ inw. & $0,1(0,4 \%)$ & $0,2(0,9 \%)$ & $17,4(62,7 \%)$ & $6,9(26,6 \%)$ & $2,1(9,5 \%)$ \\
\hline & & $20-50.000$ inw. & $0,1(0,3 \%)$ & $1,4(6,4 \%)$ & $16,6(45,7 \%)$ & $8,0(35,3 \%)$ & $2,1(12,4 \%)$ \\
\hline & & $50-100.000$ inw. & $0,1(0,1 \%)$ & $1,3(1,4 \%)$ & $31,9(57,3 \%)$ & $18,4(37,9 \%)$ & $2,2(3,4 \%)$ \\
\hline & & $100.000+$ inw. & $0,6(0,5 \%)$ & $5,1(4,5 \%)$ & $71,6(62,5 \%)$ & $34,1(31,7 \%)$ & $1,0(0,7 \%)$ \\
\hline & & Totaal & $0,1(0,3 \%)$ & $1,5(3,9 \%)$ & $25,9(53,9 \%)$ & $12,7(33,4 \%)$ & $2,0(8,6 \%)$ \\
\hline \multirow{5}{*}{$\begin{array}{l}\text { Panel C: Zowel } \\
\text { verplichte als niet- } \\
\text { verplichte indicatoren }\end{array}$} & \multirow{5}{*}{$\begin{array}{c}\text { Gemeenten in } \\
\text { steekproef met niet- } \\
\text { verplichte indicatoren }\end{array}$} & $<20.000$ inw. & $4,3(8,8 \%)$ & $0,2(0,3 \%)$ & $46,5(75,8 \%)$ & $6,9(9,1 \%)$ & $4,0(5,9 \%)$ \\
\hline & & $20-50.000$ inw. & $4,9(8,7 \%)$ & $1,4(2,2 \%)$ & $45,9(71,9 \%)$ & $8,0(10,7 \%)$ & $4,1(6,6 \%)$ \\
\hline & & $50-100.000$ inw. & $4,3(5,2 \%)$ & $1,3(1,0 \%)$ & $61,2(69,1 \%)$ & $18,4(20,1 \%)$ & $4,2(4,6 \%)$ \\
\hline & & $100.000+$ inw. & $5,1(3,6 \%)$ & $5,1(3,4 \%)$ & $99,0(67,6 \%)$ & $34,1(23,8 \%)$ & $2,3(1,5 \%)$ \\
\hline & & Totaal & $4,7(7,5 \%)$ & $1,5(1,6 \%)$ & $54,9(71,8 \%)$ & $12,7(13,7 \%)$ & $3,9(5,5 \%)$ \\
\hline
\end{tabular}

* Een leesvoorbeeld om de interpretatie van deze tabel te verduidelijken: als we alleen die gemeenten in beschouwing nemen die ook niet-verplichte indicatoren hanteren en dan kijken naar alleen die niet-verplichte indicatoren, zien we dat bij de groep gemeenten met minder dan 20.000 inwoners er per gemeente gemiddeld 17,4 output-indicatoren gehanteerd worden en heeft $62,7 \%$ van alle indicatoren die door gemeenten in die groep gehanteerd worden betrekking op een output-indicator.

${ }^{* *}$ Wij hebben er hier voor gekozen om met het oog op de leesbaarheid te volstaan met het aangeven van de aard van de 37 verplichte indicatoren, ongeacht de mate waarin deze daadwerkelijk door gemeenten worden opgenomen in hun verantwoordingsdocumenten. Voor de mate waarin zij dat in de praktijk doen, verwijzen wij naar tabel 4 .

Tabel 6. Financieel belang en aantal indicatoren per taakveld.

\begin{tabular}{|c|c|c|c|c|}
\hline & Hele steekproef & $\begin{array}{l}\text { Alle gemeenten in } \\
\text { Nederland }\end{array}$ & Hele steekproef & $\begin{array}{l}\text { Gemeenten in steekproef met } \\
\text { ook niet-verplichte indicatoren }\end{array}$ \\
\hline Taakveld & $\begin{array}{l}\text { Gemiddeld financieel } \\
\text { belang }\end{array}$ & $\begin{array}{l}\text { Aantal verplichte } \\
\text { indicatoren }\end{array}$ & $\begin{array}{l}\text { Gemiddeld totaal } \\
\text { aantal indicatoren }\end{array}$ & $\begin{array}{l}\text { Gemiddeld totaal aantal } \\
\text { indicatoren }\end{array}$ \\
\hline Bestuur en ondersteuning & $21,5 \%$ & $4(10,8 \%)$ & $7,9(13,0 \%)$ & $10,4(13,4 \%)$ \\
\hline Veiligheid & $3,2 \%$ & $6(16,2 \%)$ & $7,9(13,0 \%)$ & $9,4(12,1 \%)$ \\
\hline Verkeer, vervoer en waterstaat & $5,6 \%$ & $2(5,4 \%)$ & $3,3(5,4 \%)$ & $4,4(5,6 \%)$ \\
\hline Economie & $2,2 \%$ & $4(10,8 \%)$ & $5,3(8,7 \%)$ & $6,7(8,6 \%)$ \\
\hline Onderwijs & $4,1 \%$ & $3(8,1 \%)$ & $4,6(7,6 \%)$ & $5,7(7,4 \%)$ \\
\hline Sport, cultuur en recreatie & $7,8 \%$ & $1(2,7 \%)$ & $4,8(7,9 \%)$ & $7,3(9,5 \%)$ \\
\hline Sociaal domein & $38,3 \%$ & $10(27,1 \%)$ & $16,3(26,7 \%)$ & $20,5(26,4 \%)$ \\
\hline Volksgezondheid en milieu & $9,2 \%$ & $2(5,4 \%)$ & $4,2(6,9 \%)$ & $5,7(7,4 \%)$ \\
\hline $\begin{array}{l}\text { Volkshuisvesting, ruimtelijke ordening en } \\
\text { stedelijke vernieuwing }\end{array}$ & $8,2 \%$ & $5(13,5 \%)$ & $6,5(10,6 \%)$ & $7,5(9,7 \%)$ \\
\hline Totaal & $100,0 \%$ & $37(100,0 \%)$ & $60,8(100,0 \%)$ & $77,7(100,0 \%)$ \\
\hline
\end{tabular}

grond van het feit dat gemeenten inkomensbestedende huishoudingen zijn, verwachten dat er sprake is van een zekere samenhang hierin, alhoewel hierbij ook moet worden aangetekend dat er ook andere argumenten een rol kunnen spelen bij de keuze van het aantal indicatoren per taakveld. Zo kan het per taakveld verschillen hoe omvattend (comprehensive) indicatoren zijn, met andere woorden wellicht zijn er voor sommige taakvelden meer indicatoren nodig om een goed zicht te krijgen op de prestaties dan voor andere.

De door ons aangehouden indeling is gebaseerd op de wettelijke voorschriften die gelden voor het zogeheten taakveldoverzicht (zie het BBV en Budding and Ormel 2018). Zoals te zien is in tabel 6, vormt het Sociaal domein met 38,3\% van de uitgaven de grootste kostenpost voor gemeenten. Op de tweede plek volgt het taakveld Bestuur en ondersteuning, waarin zowel dienstverlening naar burgers en bedrijven (waaronder 'de afdeling Burgerzaken') als de kosten van het bestuursapparaat (inclusief overheadkosten) besloten ligt. De overige taakvelden volgen op grotere afstand qua financieel belang. Als we ten eerste kijken naar de wettelijk verplich- te indicatoren, dan zien we dat deze disproportioneel vaak betrekking hebben op de taakvelden Veiligheid, Economie, Onderwijs en Volkshuisvesting, ruimtelijke ordening en stedelijke vernieuwing. Anderzijds wordt er aan de taakvelden Bestuur en ondersteuning, Sport, cultuur en recreatie, Sociaal domein en Volksgezondheid en milieu minder aandacht besteed in de vorm van indicatoren dan op grond van het financieel belang daarvan verwacht had mogen worden. Interessant om te zien is dat deze relatief beperkte aandacht bij sommige taakvelden wordt gecompenseerd door hier relatief veel niet-verplichte indicatoren over te publiceren. Dat zien we met name bij de takkvelden Sport, cultuur en recreatie en Volksgezondheid en milieu, en in mindere mate bij Bestuur en ondersteuning. Bij het Sociaal domein blijft er echter sprake van een grote discrepantie tussen gemiddeld financieel belang en aandacht in de vorm van het gebruik van indicatoren. Terwijl de kosten van alle gemeenten in onze steekproef gemiddeld $38,3 \%$ van de totale uitgaven van een gemeente beslaan, heeft slechts $26,7 \%$ van de indicatoren (zowel verplicht als niet-verplicht) daarop betrekking. 


\section{Conclusies en discussie}

Nederlandse gemeenten zijn al geruime tijd bezig met de ontwikkeling en het gebruik van prestatie-indicatoren. In de loop der jaren zijn er diverse initiatieven geweest, veelal van de kant van de Rijksoverheid, om gemeenten ertoe te bewegen om indicatoren in hun verantwoordingsdocumenten op te nemen. Terwijl het hanteren van indicatoren in eerste instantie vrijwillig was, is het recent (met ingang van de begroting 2017) verplicht geworden om een lijst uniforme indicatoren in de begroting en jaarrekening op te nemen. Eén van de vragen die wij in dit artikel hebben willen beantwoorden, is welke gevolgen deze wettelijke voorschriften in de praktijk hebben. Onze resultaten laten op basis van een analyse van 107 verantwoordingsstukken zien dat $40,2 \%$ van de gemeenten momenteel volstaat met het alleen presenteren van de verplicht voorgeschreven indicatoren. Met name de kleine gemeenten beperken zich hiertoe. Dit roept de vraag op hoe nuttig het gebruik van indicatoren daadwerkelijk wordt ervaren, als het invoeren van een wettelijk voorschrift ertoe leidt dat er door een groot aantal gemeenten geen eigen pogingen meer worden gedaan om zelf indicatoren te selecteren. In termen van DiMaggio and Powell (1983) lijken normatieve (normative) argumenten voor het gebruik van indicatoren deels plaatsgemaakt te hebben voor argumenten die te maken hebben met gedwongen (coercive) gedrag. Hierbij moet tegelijkertijd worden aangetekend dat het verplicht voorschrijven van indicatoren een in de praktijk als groot ervaren probleem mogelijk wegneemt. Uit onderzoek komt namelijk naar voren dat gemeenten het adequaat definiëren van indicatoren en het meten daarvan als lastig ervaren. Het verplicht voorschrijven van een set indicatoren, waarvan de meting al door andere partijen is gebeurd, lost die problematiek voor een belangrijk deel op. Overigens constateren wij in ons onderzoek dat niet alle gemeenten zich aan de wet houden. $46,7 \%$ van de gemeenten 'vergeet' één of meerdere verplichte indicatoren in haar begroting op te nemen. Dit beeld is (helaas) consistent met Kunzler (2018) die constateert dat in de begrotingen 2018 van alle Nederlandse gemeenten ongeveer $20 \%$ van de verplichte indicatoren ontbreekt. Een laatste kanttekening die we hierover willen maken, is dat het niet ontwikkelen van eigen indicatoren ook een tijdelijke situatie kan zijn. Mogelijk zijn gemeenten er nu met name op gericht te voldoen aan de nieuwe wetgeving en worden op een later moment dergelijke initiatieven weer opgepakt.

Een ander aspect waar onze analyse zich op richtte, was de aard van de indicatoren die worden gebruikt. Zowel vanuit de praktijk als de theorie klonk de afgelopen jaren de roep om het meer hanteren van indicatoren die iets zeggen over de maatschappelijke toegevoegde waarde (outcome) van het gemeentelijk beleid (zie Wiesel and Modell 2014). Uit onze analyses blijkt dat geen van de verplichte indicatoren daar betrekking op hebben, en grotendeels als output-indicatoren moeten worden be- schouwd. We nemen verder waar dat de indicatoren die gemeenten zelf kiezen voor 33,4\% betrekking hebben op de maatschappelijke toegevoegde waarde en hiermee de eenzijdigheid van de verplichte indicatoren verzachten. Een mogelijke verklaring voor het beperkt hanteren van outcome-indicatoren kan zijn dat de andere indicatoren in de praktijk gemakkelijker meetbaar zijn. Deze bevinding sluit aan bij Micheli and Mari (2014, p. 153), die stellen dat 'scholars have observed that performance in organizations is often reduced in its meaning and scope to what is technically easier to measure of performance itself.'

Op grond van het informativeness principle (Indjejikian 1999), alsmede het feit dat gemeenten inkomensbestedende huishoudingen zijn (zie o.a. Budding and Bac 2004; Gerritsen 2007), verwachtten we dat het aantal indicatoren dat gemeenten hanteren voor hun verschillende taakgebieden in grote lijnen overeen zou komen met het financiële belang daarvan. Uit onze analyses blijkt dat er bij de verplichte indicatoren geen sprake is van een dergelijke aansluiting en dat ze disproportioneel vaak betrekking hebben op de taakvelden Veiligheid, Economie, Onderwijs en Volkshuisvesting, ruimtelijke ordening en stedelijke vernieuwing. Anderzijds wordt er aan de taakvelden Bestuur en ondersteuning, Sport, cultuur en recreatie, Sociaal domein en Volksgezondheid en milieu minder aandacht besteed in de vorm van indicatoren dan op grond van het financieel belang daarvan verwacht had mogen worden. Laatstgenoemde blijkt voor een aantal taakvelden voor een deel gecompenseerd te worden door het zelf definiëren van indicatoren op die terreinen, maar met name bij het Sociaal domein, en in mindere mate bij Bestuur en ondersteuning, blijft er sprake van een grote discrepantie tussen gemiddeld financieel belang en aandacht in de vorm van het gebruik van indicatoren.

In dit artikel hebben wij gekeken naar de praktijk van het gebruik van zowel verplichte als niet-verplichte indicatoren door gemeenten. Hierbij hebben wij vooralsnog niet geanalyseerd welke factoren verschillen tussen gemeenten verklaren. Een uitzondering hierop vormt de omvang van de gemeente. In navolging van Van Dooren (2005, p. 376) die constateert dat 'larger organizations measure more', zijn we nagegaan of we verschillen tussen grote en kleine gemeenten konden constateren. Hierbij gebruikmakend van het indelingscriterium van het aantal inwoners, constateren wij dat grote gemeenten gemiddeld genomen meer niet-verplichte indicatoren hanteren en ook dat zij verhoudingsgewijs meer gebruik maken van outcome-indicatoren.

Vervolgonderzoek kan zich richten op het verder in beeld brengen van factoren die verschillen tussen gemeenten verklaren, waarbij zowel de rol van de ambtelijke organisatie als de politieke gezagsdragers aandacht zouden moeten krijgen. Eerder onderzoek (Van Hengel et al. 2014) liet al zien dat beide groepen - zowel afzonderlijk als in samenspel met elkaar - invloed kunnen hebben op de ontwikkeling en het gebruik van prestatie-indicatoren, ook omdat ze verschillende belangen hebben. Tevens 
adviseren wij om nader onderzoek te doen naar het hanteren van (bepaalde) prestatie-indicatoren en de (gepercipieerde) tevredenheid daarover. Ten slotte zou toekomstig onderzoek zich kunnen richten op een analyse van de mogelijke verschillen tussen streefwaarden (normen) en realisatiecijfers.

- Dr. G.T. (Tjerk) Budding is opleidingsdirecteur van de Public Controllersopleidingen van het Zijlstra Center for Public Control, Governance and Leadership, onderdeel van de Vrije Universiteit Amsterdam.

- Drs. G.W. (Erwin) Ormel is adviseur bij BMC-Implementatie.

Dr. M. (Martijn) Schoute is universitair docent bij de afdeling Accounting van de School of Business and Economics, Vrije Universiteit Amsterdam.

\section{Dankwoord}

De auteurs danken Niels van Beurden, Bjorn Coenen, Rani Kharagjitsing, Jos Rademakers en Britt Slotboom (allen werkzaam bij BMC) voor hun ondersteuning inzake de verzameling van de data voor dit onderzoek en de inspirerende discussies rond dit thema.

\section{Literatuur}

- Aardema H (2002) Bedrijfsmatige schijnbewegingen, Over BBI, verstaffing en waarde-interactionisme. Bestuur \& Management Consultants (Leusden). https://www.harrieaardema.nl/aardema\%20 2002\%20bedrijfsmatige\%20schijnbewegingen.pdf

- Besluit begroting en verantwoording provincies en gemeenten. www.commissiebbv.nl

- Budding GT, Bac AD (2004) De gemeentelijke en provinciale overheid. In: Hoogendoorn MN, Klaassen J, Krens J (Eds) Externe verslaggeving in theorie en praktijk. Reed Business Information (Den Haag): 1690-1714.

- Budding GT, Griep R (2010) Prestatiemanagement bij gemeenten. B\&G 37(10): 18-21.

- Budding GT, Ormel GW (2018) Betere vergelijkbaarheid en meer transparantie verslaggeving gemeenten? Maandblad voor Accountancy \& Bedrijfseconomie 92(11/12): 391-400. https://doi. org $/ 10.5117 / \mathrm{mab} .92 .30748$

- Budding GT, Faber ASC, Vosselman EGJ (2019) Performance budgeting in the Netherlands. In: De Vries MS, Nemec J, Špaček D (Eds) Performance-Based Budgeting in the Public Sector. Palgrave Macmillan (Cham): 79-99. https://doi.org/10.1007/978-3-030-02077-4_4

- De Bruijn J (2006) Prestatiemanagement in de publieke sector. Lemma (Den Haag).

च DiMaggio PJ, Powell WW (1983) The iron cage revisited: Collective rationality and institutional isomorphism in organizational fields. American Sociological Review 48(2): 147-160. https://doi. org/10.2307/2095101

- Gerritsen E (2007) Vermogensstructuur van decentrale overheden: theorie en empirie. COELO (Groningen).

- Hyndman N, Liguori M (2016) Public sector reforms: Changing contours on an NPM landscape. Financial Accountability \& Management 32(1): 5-32. https://doi.org/10.1111/faam.12078

- Indejejikian RJ (1999) Performance evaluation and compensation research: An agency perspective. Accounting Horizons 13(2): $147-$ 157. https://doi.org/10.2308/acch.1999.13.2.147

- Jansen EP (2004) Performance measurement in governmental organizations: a contingent approach to measurement and man- agement control. Managerial Finance 30(8): 54-68. https://doi. org/10.1108/03074350410769227

- Jensen MC, Meckling WH (1976) Theory of the firm: Managerial behavior, agency costs and ownership structure. Journal of Financial Economics 3(4): 305-360. https://doi.org/10.1016/0304405X(76)90026-X

- Kaplan RS, Johnson HT (1987) Relevance Lost: The Rise and Fall of Management Accounting. Harvard Business School Press (Boston).

- Kunzler T (2018). Beleidsindicatoren BBV gemeenten - begroting 2018. https://data.openstate.eu/dataset/beleidsindicatoren-bbv-gemeenten-begroting-2018

- Micheli P, Mari L (2014) The theory and practice of performance management. Management Accounting Research 25(2): 147-156. https://doi.org/10.1016/j.mar.2013.07.005

- Schilder NAC, Aardema H, Van Dam M, Koldenhoff R, Geuzendam, HM (2010) Evaluatie financiële functie gemeenten en provincies. BMC Advies en Management (Amersfoort).

- Ter Bogt HJ, Van Helden GJ (1994) Kwaliteit van prestatiemeting bij gemeentelijke overheden. Bestuurskunde 5(1): 2-12.

- Ter Bogt HJ, Van Helden GJ (2000) Accounting change in Dutch government: Exploring the gap between expectations and realizations. Management Accounting Research 11(2): 263-279. https:// doi.org/10.1006/mare.2000.0132

- Van Dooren W (2005) What makes organizations measure? Hypotheses on the causes and conditions for performance measurement. Financial Accountability \& Management 21(3): 363-384. https:// doi.org/10.1111/j.0267-4424.2005.00225.x

- Van Hengel HG, Budding GT, Groot TLCM (2014) Loosely coupled results control in Dutch municipalities. Financial Accountability \& Management 30(1): 49-74. https://doi.org/10.1111/faam.12027

- Wiesel F, Modell, S (2014) From New Public Management to New Public Governance? Hybridization and implications for public sector consumerism. Financial Accountability \& Management 30(2): 175-205. https://doi.org/10.1111/faam.12033 